\title{
Penerapan Analisis Jalur dalam Mengidentifikasi Penyebab Fluktuasi Harga Cabai Merah di Kabupaten Aceh Jaya
}

\author{
Reza Septian Pradana \\ Fungsional Statistisi Ahli BPS Kabupaten Aceh Jaya \\ *email: reza.sp@bps.go.id \\ Diterima: Agustus 2020; Disetujui: Februari 2020; Dipublish: April 2021
}

\begin{abstract}
Abstrak
Kabupaten Aceh Jaya merupakan salah satu daerah penghasil cabai merah di Provinsi Aceh. Secara umum komoditas pertanian tidak terkecuali cabai merah mempunyai masalah fluktuasi harga. Fluktuasi harga cabai merah menyebabkan risiko kerugian bagi produsen/ petani dan menurunnya daya beli konsumen. Penelitian ini bertujuan untuk mengidentifikasi penyebab fluktuasi harga cabai merah baik pada tingkat produsen/ petani maupun konsumen di Kabupaten Aceh Jaya periode januari 2017 hingga desember 2019 dengan menggunakan analisis jalur. Hasil estimasi menunjukkan bahwa produksi cabai merah secara signifikan berpengaruh langsung terhadap harga cabai merah baik pada tingkat produsen/ petani maupun konsumen di Kabupaten Aceh Jaya. Hasil estimasi juga menunjukkan bahwa adanya pengaruh tidak langsung produksi cabai merah terhadap harga cabai merah pada tingkat konsumen di Kabupaten Aceh Jaya. Produksi cabai merah secara signifikan berpengaruh terhadap harga cabai merah pada tingkat konsumen melalui harga cabai merah pada tingkat produsen. Sebaliknya, harga pupuk urea tidak secara signifikan berpengaruh terhadap harga cabai merah baik secara langsung maupun tidak langsung. Dengan demikian, diperlukan upaya peningkatan produksi cabai merah serta penetapan harga cabai merah tertinggi dan terendah khususnya pada tingkat produsen/ petani di Kabupaten Aceh Jaya.
\end{abstract}

Kata Kunci: Analisis Jalur, Cabai Merah, Fluktuasi, Harga

\begin{abstract}
Aceh Jaya Regency is one of the red chili producing areas in Aceh Province. Generally, agricultural commodities, including red chili, have a problem with price fluctuations. The price fluctuation of red chili causes the risk of loss for producers / farmers and decreases consumer purchasing power. This study aims to identify the causes of red chili price fluctuations at both the producer/farmer and consumer levels in Aceh Jaya Regency period january 2017 to december 2019 by using path analysis. The estimation results show that the production of red chili significantly has a direct effect on the price of red chili, at both the producer/farmer and consumer levels in Aceh Jaya Regency. The estimation results also show that there is an indirect effect of red chili production on the price of red chili at the consumer level in Aceh Jaya Regency. Red chili production significantly influents to the price of red chili at the consumer level through the price of red chili at the producer level. On the other hand, the price of urea fertilizer does not significantly influent to the price of red chili, either directly or indirectly. Thus, efforts are needed to increase the production of red chili and determine the ceiling and floor red chili prices, especially at the producer/farmer level in Aceh Jaya Regency.
\end{abstract}

Keywords: Path Analysis, Red Chili, Fluctuation, Price

\section{PENDAHULUAN}

Cabai merah merupakan komoditas hortikultura yang sangat digemari oleh masyarakat indonesia. Hal ini dikarenakan cabai merah memiliki nilai ekonomi tinggi bagi petani serta memiliki rasa pedas dan aroma khas sehingga bagi orang-orang tertentu dapat membangkitkan selera makan. 
Darma, dkk (2018) mengatakan bahwa permintaan cabai merah diperkirakan akan berkelanjutan karena kebiasaan masyarakat mengkonsumsi cabai merah dalam bentuk segar untuk kehidupan sehari-hari dan belum terdapatnya bahan yang dapat mensubstitusi kebutuhan cabai tersebut. Selain itu, komoditas tersebut tertuang dalam peraturan menteri perdagangan No.63/ m.dag/per/09/2016. Peraturan itu merupakan tindak lanjut dalam peraturan presiden No.71/2015 tentang penetapan dan penyimpanan barang penting.

Cabai merah tersebar di Indonesia. Kabupaten Aceh Jaya merupakan salah satu kabupaten penghasil cabai merah di Provinsi Aceh. Berdasarkan data Dinas Pertanian Provinsi Aceh, produksi cabai merah di Kabupaten Aceh Jaya mencapai 6.245 kuintal dengan produktivitas 52,48 kuintal per hektar pada tahun 2019. Angka ini menjadikan Kabupaten Aceh Jaya sebagai penghasil cabai merah terbesar ke-sebelas di Provinsi Aceh setelah Kabupaten Aceh Timur. Cabai merah dihasilkan oleh seluruh kecamatan di Kabupaten Aceh Jaya. Teunom dan Pasie Raya merupakan kecamatan penghasil cabai merah terbesar di Kabupaten Aceh Jaya dengan produksi pada masing-masing kecamatan tersebut sebesar 1.260 kuintal dan 1.450 kuintal pada tahun 2019.

Berdasarkan data Dinas Pertanian Kabupaten Aceh Jaya, luas tanaman cabai merah hingga akhir tahun 2019 mencapai 22 hektar. Tanaman cabai merah paling luas ditanam di Kecamatan Darul Hikmah, yakni mencapai 5 hektar.
Selama tahun 2019, luas penanaman baru untuk komoditas cabai merah mencapai 9 hektar.

Secara umum komoditas pertanian mempunyai masalah fluktuasi harga tidak terkecuali cabai merah sebagai salah satu dari komoditas hortikultura strategis. Menurut Saptana, dkk (2006), komoditas hortikultura secara intrinsik memiliki sifat cepat busuk, rusak, dan susut besar. Hal ini merupakan masalah yang dapat menimbulkan risiko fisik dan harga.

Fluktuasi harga yang tidak terkendali dapat menyebabkan kerugian bagi konsumen maupun produsen. Bagi produsen, sulit untuk memprediksi bisnis baik dalam perhitungan rugi laba maupun manajemen risiko sehingga seringkali fluktuasi harga hanya menguntungkan para pedagang yang mampu mengelola stok secara baik dan cermat (Windhy, dkk, 2018).

Hal yang sama juga dialami oleh konsumen. Harga bahan makanan yang stabil merupakan harapan konsumen. Cabai menjadi salah satu bumbu masakan yang harus ada pada menu harian sebagian besar masyarakat Indonesia (Nauly 2016). Harga cabai yang melonjak akan berdampak pada menurunnya daya beli konsumen. Konsumen memerlukan kepastian harga cabai merah agar biaya yang dikeluarkan untuk melakukan pembelian cabai merah dapat dikendalikan.

Harga suatu barang dan jasa ditentukan oleh interaksi dari kekuatan permintaan dan penawaran (Sukirno, 2005). Berdasarkan data dari Badan Pusat Statistik, konsumsi cabai merah per kapita sebulan penduduk Kabupaten 
Aceh Jaya pada tahun 2018 mencapai 0,21 kg. Angka ini menunjukkan kenaikan apabila dibandingkan konsumsi cabai merah per kapita sebulan pada tahun 2017 yang mencapai 0,20 kg. Dengan jumlah penduduk Kabupaten Aceh Jaya pada tahun 2017 dan 2018 masing-masing sebesar 89.618 jiwa dan 91.087 jiwa, total konsumsi cabai merah seluruh penduduk Kabupaten Aceh Jaya sebanyak 215 ton pada tahun 2017 dan 230 ton pada tahun 2018. Kenaikan permintaan ini mengakibatkan harga cabai merah di Kabupaten Aceh Jaya meningkat 9,12 persen pada tingkat konsumen pada tahun 2018 dibandingkan tahun 2017.

Berdasarkan Data Dinas Pertanian Kabupaten Aceh Jaya selama tahun 2019 produksi cabai merah tertinggi terjadi pada bulan Januari 2019 yakni sebesar 965 kuintal. Angka ini menunjukkan peningkatan apabila dibandingkan bulan Desember 2018 yang mencapai 750 kuintal. Peningkatan produksi pada bulan Januari 2019 mengakibatkan harga harga cabai merah di Kabupaten Aceh Jaya mengalami penurunan. Berdasarkan data Badan Pusat Statistik, penurunan harga cabai merah di Kabupaten Aceh Jaya pada tingkat konsumen sebesar 32,37 persen pada bulan Januari 2019 apabila dibandingkan Desember 2018.

Kenaikan harga cabai merah sangat tergantung pada musim panen dan musim tanam serta pengaruh iklim (Fajri, dkk, 2017). Menurut Firdaus (2012), beberapa faktor yang menyebabkan penawaran barang pertanian tidak elastis adalah barang pertanian tergantung pada faktor alam sehingga produksi bersifat musiman dan kapasitas memproduksi sektor pertanian cenderung mencapai tingkat tinggi tidak terpengaruh oleh perubahan permintaan. Penelitian yang dilakukan oleh Fajri, dkk (2017) serta Nurvitasari, dkk (2018) menujukkan bahwa harga cabai merah dipengaruhi oleh produksi cabai merah. Pada daerah penghasil cabai merah, ketersediaan cabai merah akan melimpah pada musim panen sehingga mengakibatkan harga cabai merah akan lebih murah dengan asumsi permintaan cabai merah dan biaya produksi konstan.

Selain produksi cabai merah, fluktuasi harga cabai merah dipengaruhi oleh faktor biaya produksi (Farid \& Subekti, 2012). Biaya pupuk merupakan biaya terbesar kedua yang dikeluarkan petani setelah tenaga kerja sehingga jika harga pupuk naik pada musim tanam maka harga cabai akan naik pada musim panen (Nauly, 2016). Pupuk anorganik cenderung lebih banyak digunakan oleh petani dengan alasan lebih cepat dalam penyediaan unsur hara dibandingkan dengan pupuk organik (Wijayanti, dkk, 2013). Urea merupakan salah satu jenis pupuk anorganik yang banyak digunakan oleh petani. Menurut Wijayanti, dkk (2013), unsur nitrogen dalam pupuk urea berperan membuat daun tanaman lebih hijau segar dan banyak mengandung butir hijau daun (chlorophyl) yang mempunyai peranan sangat penting dalam proses fotosintesis, mempercepat pertumbuhan tanaman (tinggi, jumlah anakan, cabang dan lainlain), dan menambah kandungan protein tanaman. 
Harga cabai merah yang terbentuk pada tingkat konsumen dapat dipengaruhi oleh harga cabai merah pada tingkat produsen/ petani, khususnya untuk daerah penghasil cabai merah. Penelitian yang dilakukan oleh Elvina, dkk (2016) mengenai transmisi dan pembentukkan harga cabai merah serta perilaku pasar antar lembaga pemasaran cabai merah di Indonesia menunjukkan bahwa transmisi harga pada rantai pemasaran cabai merah terjadi secara satu arah yaitu dari grosir ke produsen, grosir ke konsumen, dan produsen ke konsumen.

Hasil penelitian yang dilakukan oleh Elvina, dkk (2016) juga memberikan informasi bahwa perubahan harga produsen dipengaruhi oleh pasokan dan harga produsen periode sebelumnya kemudian faktor yang memengaruhi perubahan harga konsumen dipengaruhi oleh harga grosir, harga produsen, dan jumlah pasokan cabai merah. Berdasarkan hasil penelitian ini, terlihat adanya indikasi pengaruh langsung dan tidak langsung faktor pembentuk harga cabai merah. Produksi cabai merah dapat berpengaruh langsung terhadap pembentukkan harga cabai merah baik pada tingkat produsen/ petani maupun konsumen. Secara tidak langsung, produksi cabai merah berpengaruh terhadap harga cabai merah pada tingkat konsumen melalui harga cabai merah pada tingkat produsen. Dengan demikian, salah satu analisis yang cocok untuk mengidentifikasi penyebab fluktuasi harga cabai merah ini adalah dengan analisis jalur (path analysis).

Berdasarkan pemikiran diatas, diperlukan suatu analisis untuk mengidentifikasi penyebab pergerakan harga cabai merah di Kabupaten Aceh Jaya. Dengan demikian, diperoleh informasi terkait upaya yang dapat dilakukan untuk mengendalikan harga cabai merah baik pada tingkat produsen/ petani maupun konsumen di Kabupaten Aceh Jaya.

Produksi cabai merah dan harga pupuk urea diduga berpengaruh signifikan terhadap harga cabai merah baik pada tingkat petani/ produsen maupun tingkat konsumen di Kabupaten Aceh Jaya. Selain itu, sebagai salah satu daerah penghasil cabai merah di Provinsi Aceh, diduga adanya transmisi harga cabai merah dari tingkat petani/ produsen ke tingkat konsumen di Kabupaten Aceh Jaya.

\section{METODE PENELITIAN}

Data yang digunakan dalam penelitian ini bersumber dari Badan Pusat Statistik (BPS) dan Dinas Pertanian Kabupaten Aceh Jaya. Data harga cabai merah baik pada tingkat produsen/ petani maupun konsumen serta data harga pupuk urea di Kabupaten Aceh Jaya merupakan hasil pengumpulan data survei harga perdesaan (SHPED) oleh BPS. Kemudian, data produksi cabai merah di Kabupaten Aceh Jaya diperoleh dari laporan bulanan statistik pertanian hortikultura (SPH) sayuran dan buahbuahan semusim (SBS) yang dikumpulkan oleh Mantri Tani/ KCD Dinas Pertanian Kabupaten Aceh Jaya dan dilaporkan ke BPS pada setiap bulannya. Data yang digunakan dalam penelitian ini adalah data deret waktu (time series) bulanan periode januari 2017 hingga desember 2019. 
Penelitian ini menggunakan analisis jalur (path analysis). Analisis jalur merupakan perluasan dari analisis regresi linier berganda, atau analisis jalur adalah penggunaan analisis regresi untuk menaksir hubungan kausalitas antar variabel (model kasual) yang telah ditetapkan sebelumnya berdasarkan teori.

Menurut Jonathan Sarwono (2010), ada enam tahapan dalam melakukan analisis jalur. Pertama, merancang model didasarkan pada teori. Kedua, membuat hipotesis. Ketiga, menentukan model diagram jalur berdasarkan pada variabel-variabel yang dikaji. Keempat, membuat diagram jalur. Kelima, membuat persamaan struktural. Keenam, melakukan prosedur path analysis.

Adapun diagram jalur dalam penelitian ini adalah sebagai berikut:

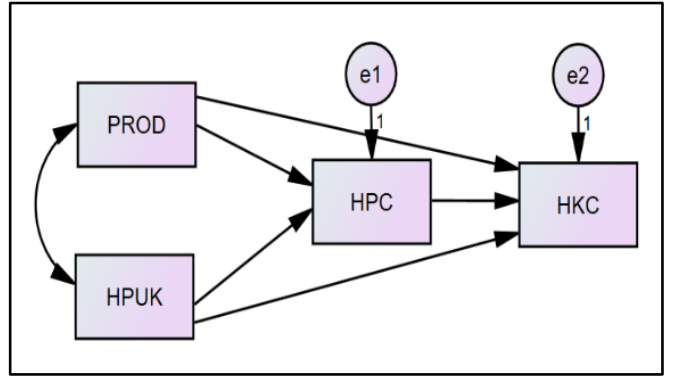

Gambar 1 Diagram Jalur

Berdasarkan diagram jalur diatas, dapat disusun persamaan regresi dalam penelitian ini sebagai berikut:

HPCt $=\alpha_{0}+\alpha_{1}$ PROD $_{t}+\alpha_{2}$ HPUK $_{t}+$ $\mathrm{e} 1_{\mathrm{t}}$

$\mathrm{HKCt}=\beta_{0}+\beta_{1} \mathrm{PROD}_{\mathrm{t}}+\beta_{2} \mathrm{HPUK}_{\mathrm{t}}+\beta_{3} \mathrm{HPC}_{\mathrm{t}}$ $+\mathrm{e} 2 \mathrm{t}$

dimana:

$\alpha_{0}, \beta_{0} \quad:$ intercept

$\alpha_{1}, \alpha_{2}, \beta_{1}, \beta_{2}, \beta_{3}$ : koefisien regresi

$\mathrm{HPC}_{\mathrm{t}} \quad$ : logaritma natural harga cabai merah pada tingkat

petani/produsen

periode $t$

$\mathrm{HKC}_{\mathrm{t}}$

: logaritma natural

harga cabai merah

pada tingkat

konsumen periode $t$

PROD $_{t} \quad$ : logaritma natural produksi cabai merah periode $t$

HPUK $_{\mathrm{t}} \quad$ : logaritma natural harga pupuk urea periode $t$

$\mathrm{e} 1_{\mathrm{t}}, \mathrm{e} 2_{\mathrm{t}} \quad:$ residual periode $t$

Untuk mengetahui keberadaan pengaruh tidak langsung, digunakan uji Z Sobel. Dalam penelitian ini, variabel harga cabai merah pada tingkat produsen/ petani sebagai mediator dalam pengujian pengaruh tidak langsung. Variabel produksi cabai merah dan harga pupuk urea menjadi variabel independen dan harga cabai merah pada tingkat konsumen menjadi variabel dependen dalam penelitian ini. Adapun rumus penghitungan nilai statistik $\mathrm{Z}$ Sobel (MacKinnon, D. P., Warsi, G., \& Dwyer 1995) dan yang digunakan dalam penelitian ini adalah sebagai berikut:

$\left.\mathrm{Z}_{\mathrm{PROD}}=\frac{\alpha_{1} \times \beta_{3}}{\sqrt{\left(\alpha_{1}^{2} \times \mathrm{s}_{\mathrm{HPC}}^{2}\right)+\left(\beta_{3}^{2} \times \mathrm{s}_{\mathrm{PROD}}^{2}\right)}} \ldots . .3\right)$

$\left.\mathrm{Z}_{\mathrm{HPUK}}=\frac{\alpha_{2} \times \beta_{3}}{\sqrt{\left(\alpha_{2}^{2} \times \mathrm{s}_{\mathrm{HPC}}^{2}\right)+\left(\beta_{3}^{2} \times \mathrm{s}_{\mathrm{HPUK}}^{2}\right)}} \ldots \ldots . . .4\right)$

dimana:

$Z_{P R O D}:$ nilai Z Sobel untuk pengaruh tidak langsung produksi cabai merah terhadap harga cabai merah pada tingkat konsumen

$Z_{\text {HPUK }}$ : nilai Z Sobel untuk pengaruh tidak langsung harga pupuk urea 
terhadap harga cabai merah pada tingkat konsumen

$S_{P R O D}$ :standard error produksi cabai merah
$S_{\text {HPUK }}$ :standard error harga pupuk urea

$S_{H P C}$ : standard error harga cabai merah pada tingkat produsen/ petani

Tabel 1 Statistik Deskriptif Harga Cabai Merah, Produksi Cabai Merah, dan Harga Pupuk di Kabupaten Aceh Jaya Periode Januari 2017 - Desember 2019

\begin{tabular}{lcccc}
\hline & $\begin{array}{c}\text { Harga Cabai Merah } \\
\text { Tingkat Konsumen } \\
\text { (rupiah) }\end{array}$ & $\begin{array}{c}\text { Harga Cabai Merah } \\
\text { Tingkat Petani/ } \\
\text { Produsen } \\
\text { (rupiah) }\end{array}$ & $\begin{array}{c}\text { Produksi } \\
\text { Cabai Merah } \\
\text { (kuintal) }\end{array}$ & $\begin{array}{c}\text { Harga } \\
\text { Pupuk Urea } \\
\text { (rupiah) }\end{array}$ \\
\hline Mean & 32.166 & 23.172 & 589 & 2.774 \\
Maximum & 66.601 & 45.166 & 1.350 & 3.000 \\
Minimum & 15.314 & 8.660 & 235 & 2.500 \\
CV & 37,56 & 43,24 & 43,94 & 8,12 \\
\hline
\end{tabular}

Sumber : Data Primer (diolah), 2020

HASIL DAN PEMBAHASAN

Perkembangan Harga Cabai Merah, Produksi Cabai Merah, dan Harga Pupuk di Kabupaten Aceh Jaya Periode Januari 2017 - Desember 2019

Berdasarkan tabel 1, diperoleh informasi bahwa produksi cabai merah paling berfluktuatif. Hal ini ditunjukkan dengan nilai Coefficient of Variation (CV) dari data produksi cabai merah di Kabupaten Aceh Jaya periode januari 2017 hingga desember 2019 tertinggi yakni sebesar 43,94 persen. Produksi cabai merah di Kabupaten Aceh Jaya sangat bergantung pada anomali cuaca. Kondisi cuaca yang tidak menentu mengakibatkan produksi cabai merah di Kabupaten Aceh Jaya mengalamai fluktuasi. Hal ini serupa dengan penelitian yang dilakukan Nauly (2016) yang menunjukkan bahwa fluktuasi produksi cabai merah disebabkan waktu tanam cabai yang sangat dipengaruhi cuaca.

Harga cabai merah pada tingkat produsen/ petani sering mengalami fluktuasi harga yang tidak menentu. Di Kabupaten Aceh Jaya, harga cabai merah pada tingkat produsen/ petani cenderung lebih berfluktuatif dibandingkan harga cabai merah pada tingkat konsumen. Hal ini ditunjukkan dengan nilai Coefficient of Variation (CV) harga cabai merah pada tingkat produsen/ petani lebih besar dibandingkan harga cabai merah pada tingkat konsumen. Petani cabai merah di Kabupaten Aceh Jaya merupakan petani kecil yang sebagian besar tidak dapat memprediksikan produksi dan harga cabai merah yang akan terjadi dipasaran. Walaupun nilai Coefficient of Variation (CV) harga cabai merah pada tingkat produsen lebih rendah dari pada produksinya namun perbedaannya tidak terlalu besar yakni hanya 0,70 persen. Hal ini mengindikasikan harga cabai merah pada tingkat produsen/ petani dipengaruhi oleh produksi cabai merah itu sendiri.

Harga pupuk urea di Kabupaten Aceh Jaya cenderung paling stabil selama periode januari 2017 hingga desember 
2019 dikarenakan adanya subsidi dari pemerintah. Harga pupuk urea cenderung paling tidak berfluktuatif. Hal ini ditunjukkan dengan nilai Coefficient of Variation (CV) harga pupuk urea terendah, yakni sebesar 8,12 persen.

Berdasarkan gambar 2, terlihat bahwa secara umum pergerakan harga cabai merah pada tingkat konsumen seiring dengan pergerakan harga cabai merah pada tingkat produsen/ petani. Ini menunjukkan adanya indikasi penetapan harga cabai merah pada tingkat konsumen dipengaruhi oleh harga cabai merah pada tingkat produsen/ petani di Kabupaten Aceh Jaya.

Harga cabai merah pada tingkat konsumen di Kabupaten Aceh Jaya berada pada kisaran 15 ribu rupiah per kg hingga 66 ribu rupiah per $\mathrm{kg}$ atau secara rata-rata tidak jauh dari 32 ribu rupiah per kg selama periode Januari 2017 hingga Desember 2019. Harga cabai merah pada tingkat konsumen sangat rendah terjadi pada bulan Februari 2019 sedangkan sangat tinggi terjadi pada bulan Juli 2019. Persentase kenaikan harga cabai merah pada tingkat konsumen tertinggi terjadi pada bulan Agustus 2017, yakni sebesar 122,43 persen. Persentase penurunan harga cabai merah pada tingkat konsumen tertinggi terjadi pada bulan Februari 2017, yakni sebesar 44,42 persen.

Harga cabai merah pada tingkat produsen/ petani di Kabupaten Aceh Jaya berada pada kisaran 8 ribu rupiah per kg hingga 45 ribu rupiah per kg atau secara rata-rata tidak jauh dari 23 ribu rupiah per kg selama periode Januari 2017 hingga Desember 2019. Harga cabai merah pada tingkat

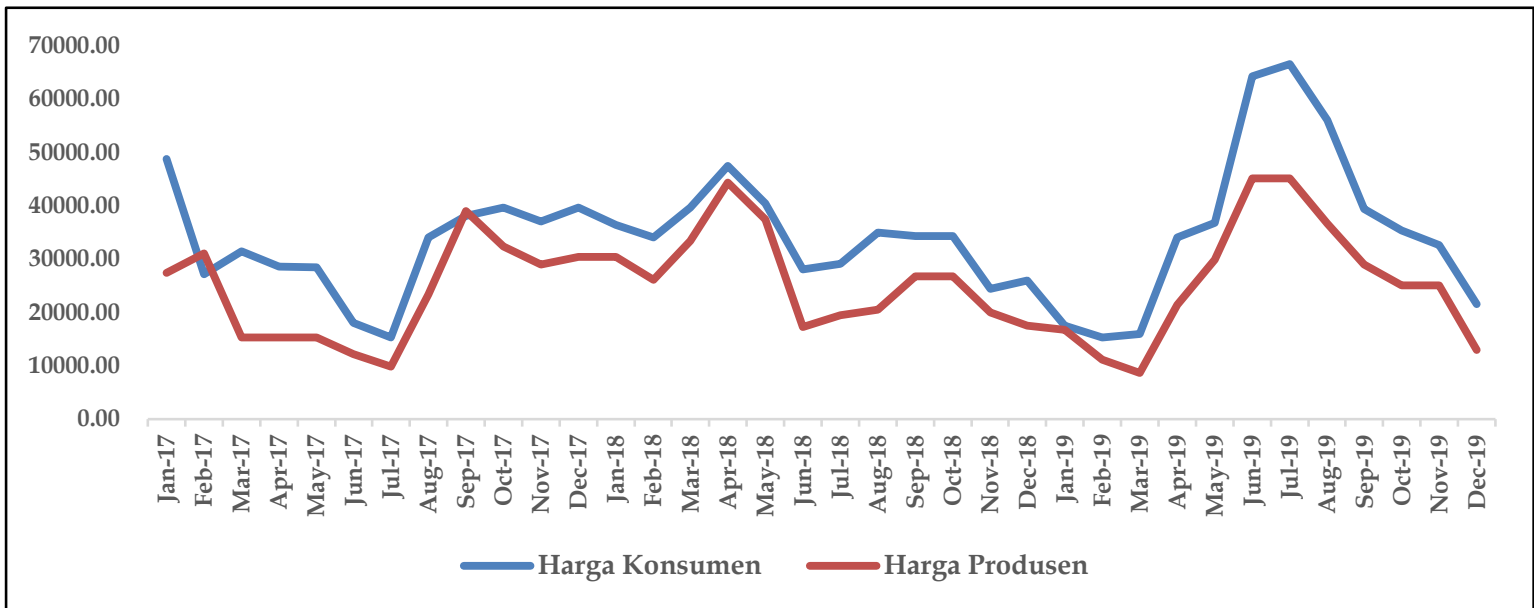

Gambar 2 Perkembangan Harga Cabai Merah pada Tingkat Produsen/ Petani dan Konsumen (rupiah) di Kabupaten Aceh Jaya Periode Januari 2017- Desember 2019

produsen/ petani sangat rendah terjadi pada bulan Maret 2019 sedangkan sangat tinggi terjadi pada bulan Juli 2019. Persentase kenaikan harga cabai merah pada tingkat produsen/ petani tertinggi terjadi pada bulan April 2019, yakni sebesar 148,33 persen. Persentase penurunan harga cabai merah pada tingkat konsumen tertinggi terjadi pada bulan Juni 2018, yakni sebesar 53,71 persen. 


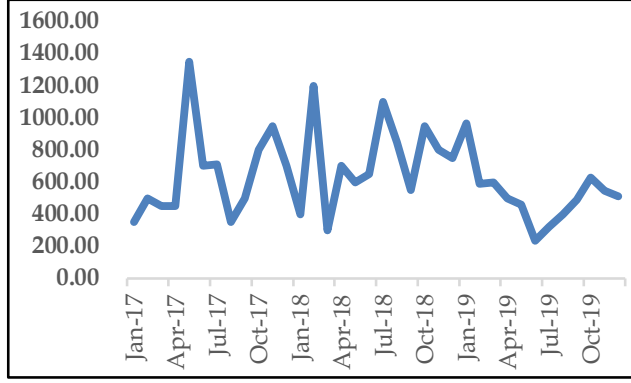

Gambar 3 Perkembangan Produksi Cabai Merah (kuintal) di Kabupaten Aceh Jaya Periode Januari 2017-Desember 2019

Pembentukkan harga cabai merah baik pada tingkat produsen/ petani maupun konsumen tidak lepas dari ketersediaan cabai merah itu sendiri. Produksi cabai merah di Kabupaten Aceh Jaya berada pada kisaran 235 kuintal hingga 1.350 kuintal atau secara rata-rata tidak jauh dari 589 kuintal selama periode Januari 2017 hingga Desember 2019. Produksi cabai merah sangat sedikit terjadi pada bulan Juni 2019 sedangkan sangat banyak terjadi pada bulan Mei 2017. Persentase kenaikan produksi cabai merah tertinggi terjadi pada bulan Mei 2017 dan Februari 2018, yakni sebesar 200 persen. Persentase penurunan produksi cabai merah tertinggi terjadi pada bulan Maret 2018, yakni sebesar 75 persen.

Selain itu, harga bahan baku (input) juga berperan dalam pembentukkan harga cabai merah. Pupuk merupakan salah satu bahan baku (input) pelengkap pada kegiatan penanaman cabai merah. Salah satu pupuk yang tergolong sering digunakan oleh petani cabai merah adalah pupuk urea. Harga pupuk urea di Kabupaten Aceh Jaya berada pada kisaran 2.500 rupiah per kg hingga 3.000 rupiah per kg atau secara rata-rata tidak jauh dari 2.774 rupiah per kg selama periode Januari 2017 hingga Desember 2019. Pergerakan harga pupuk urea cenderung stabil. Selama periode Januari 2017 hingga Desember 2017, rata-rata harga pupuk urea tidak bergerak di posisi 2.500 rupiah. Mulai januari 2018, harga pupuk urea naik 9,54 persen. Pada bulan agustus 2018 harga pupuk urea di Kabupaten Aceh Jaya naik kembali sebesar 9,54 persen. Hingga bulan desember 2019, rata-rata harga pupuk urea di Kabupaten Aceh Jaya sebesar 3.000 rupiah per $\mathrm{kg}$.

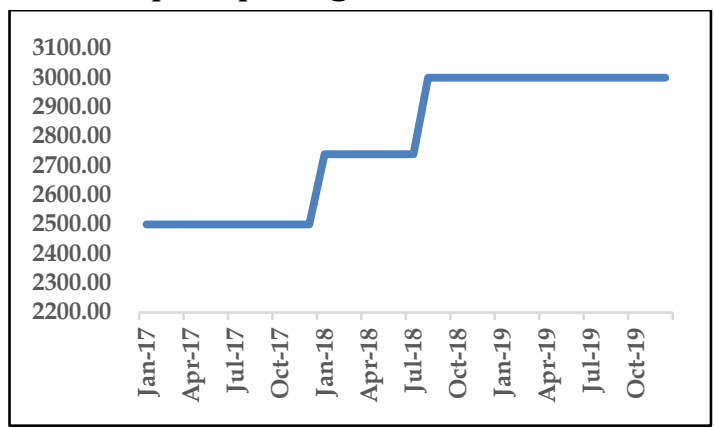

Gambar 4 Perkembangan Harga Pupuk Urea (rupiah) di Kabupaten Aceh Jaya Periode Januari 2017-Desember 2019

\section{Identifikasi Penyebab Pergerakan Harga Cabai Merah di Kabupaten Aceh Jaya}

Untuk mengidentifik asi penyebab pergerakan harga cabai merah di Kabupaten Aceh Jaya dalam penelitian ini, digunakan analisis jalur (path analysis). Dengan menggunakan software SPSS AMOS 24, diperoleh hasil sebagai berikut:

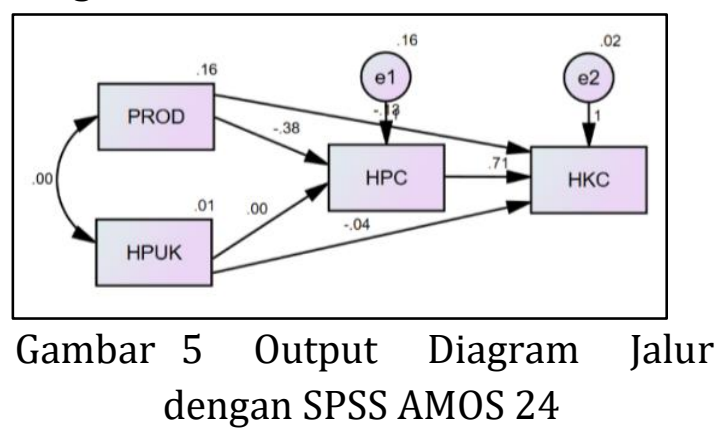


Dalam penelitian ini terdapat dua persamaan yang terbentuk, yakni persamaan untuk harga cabai merah pada tingkat produsen/petani dan harga cabai merah pada tingkat konsumen di Kabupaten Aceh Jaya. Nilai R squared untuk persamaan harga cabai merah pada tingkat produsen/ petani sebesar 0,121 persen. Hal ini berarti produksi cabai merah (PROD) dan harga pupuk urea (HPUK) dapat menjelaskan variasi harga cabai merah pada tingkat produsen/ petani (HPC) di Kabupaten Aceh Jaya sebesar 12,10 persen. Nilai R squared untuk persamaan harga cabai merah pada tingkat konsumen jauh lebih besar dibandingkan harga cabai merah pada tingkat produsen/ petani, yakni sebesar 0,825. Hal ini berarti variasi harga cabai merah pada tingkat konsumen (HKC) di Kabupaten Aceh Jaya dapat dijelaskan oleh produksi cabai merah (PROD), harga pupuk urea (HPUK), dan harga cabai merah pada tingkat produsen/ petani (HPC) sebesar 82,50 persen.

Berdasarkan tabel 3, diperoleh informasi bahwa bahwa model yang terbentuk sudah cocok (fit). Model yang terbentuk dapat digunakan untuk menjelaskan pengaruh variabel independen terhadap variabel dependen dalam penelitian ini. Hal ini dibuktikan dengan nilai $P$-Value dari CMIN sebesar 0,000 (lebih kecil dari alpha 0,10).

Tabel 2 Nilai $R$ Squared Persamaan Harga Cabai Merah pada Tingkat Produsen (HPC) dan Konsumen (HKC)

\begin{tabular}{cc}
\hline & Estimate \\
\hline HPC & .121 \\
HKC & .825 \\
\hline
\end{tabular}

Sumber : Data Primer (diolah), 2020
Output pada tabel 4 memberikan informasi mengenai keberadaan pengaruh langsung dari variabel independen terhadap variabel dependen. Produksi cabai merah secara langsung berpengaruh signifikan terhadap harga cabai merah baik pada tingkat produsen/ petani maupun konsumen di Kabupaten Aceh Jaya. Hal ini ditunjukkan dengan $p$ value yang lebih kecil dari 0,10. Kondisi cuaca yang tidak menentu diiringi curah hujan yang masih tinggi dapat menurunkan produksi cabai merah di Kabupaten Aceh Jaya. Penurunan produksi ini mengakibatkan supply dari cabai merah di Kabupaten Aceh Jaya berkurang. Permintaan cabai merah untuk keperluan rumah tangga diperkirakan akan berkelanjutan seiring dengan meningkatnya jumlah penduduk. Salah satu faktor yang mempengaruhinya antara lain kebiasaan masyarakat Kabupaten Aceh Jaya yang mengkonsumsi cabai merah dalam bentuk segar untuk keperluan sehari-hari. Hal ini jelas akan mengakibatkan harga cabai merah akan terus naik.

Selain itu, harga cabai merah pada tingkat produsen/ petani juga secara langsung berpengaruh signifikan terhadap harga cabai merah pada tingkat konsumen di Kabupaten Aceh Jaya. Sebaliknya, harga pupuk urea tidak secara signifikan berpengaruh langsung terhadap harga cabai merah baik pada tingkat produsen/ petani maupun konsumen. Hal ini ditunjukkan dengan $p$ value yang lebih besar dari 0,10.

Produksi cabai merah memiliki pengaruh langsung yang negatif terhadap harga cabai merah baik pada tingkat produsen/ petani maupun 
konsumen. Hal ini berarti jika produksi cabai merah meningkat maka harga cabai merah akan
Secara langsung turun baik pada tingkat produsen/ petani maupun konsumen.

Tabel 3. Hasil Pengujian Goodness of Fit dari Model Terbentuk

\begin{tabular}{lrrrrr}
\hline Model & NPAR & CMIN & DF & P & CMIN/DF \\
\hline Default model & 10 & .000 & 0 & & \\
Saturated model & 10 & .000 & 0 & & \\
Independence model & 4 & 65.714 & 6 & .000 & 10.952 \\
\hline
\end{tabular}

Sumber : Data Primer (diolah), 2020

Koefisien regresi variabel produksi cabai merah pada persamaan harga cabai merah di tingkat produsen/ petani lebih besar dibandingkan pada persamaan harga cabai merah di tingkat konsumen. Koefisien regresi variabel produksi cabai merah pada persamaan harga cabai merah pada tingkat produsen/ petani sebesar -0,376. Artinya, dengan tingkat keyakinan 90 persen, setiap peningkatan produksi cabai merah sebesar 1 persen secara langsung akan mengakibatkan harga cabai merah pada tingkat produsen/ petani di Kabupaten Aceh Jaya turun sebesar 0,376 persen. Koefisien regresi variabel produksi cabai merah pada persamaan harga cabai merah pada tingkat konsumen sebesar -0,127. Artinya, dengan tingkat kepercayaan 90 persen setiap peningkatan produksi cabai merah sebesar 1 persen secara langsung akan mengakibatkan harga cabai merah pada tingkat konsumen di Kabupaten Aceh Jaya turun sebesar 0,127 persen. Hal ini sesuai dengan hasil penelitian yang dilakukan oleh Elvina, dkk (2016); Fajri, dkk (2017); serta Nurvitasari, dkk (2018).

Sebaliknya, harga cabai merah pada tingkat produsen/petani memiliki pengaruh langsung yang positif terhadap harga cabai merah pada tingkat konsumen. Hal ini berarti jika harga cabai merah pada tingkat produsen/ petani naik maka harga cabai merah pada tingkat konsumen di Kabupaten Aceh Jaya secara langsung akan naik. Koefisien regresi variabel harga cabai merah pada tingkat produsen/ petani pada persamaan harga cabai merah pada tingkat konsumen sebesar 0,713 .

Tabel 4 Hasil Estimasi Analisis Jalur (Path Analysis) dengan Software SPSS AMOS 24

\begin{tabular}{rllrrrrl}
\hline & & & Estimate & S.E. & C.R. & P & Label \\
\hline HPC & $<---$ & PROD & -.376 & .172 & -2.191 & .028 & par_2 \\
HPC & $<---$ & HPUK & -.003 & .842 & -.003 & .997 & par_3 \\
HKC & $<---$ & PROD & -.127 & .069 & -1.849 & .064 & par_4 \\
HKC & $<---$ & HPUK & -.043 & .316 & -.137 & .891 & par_5 \\
HKC & $<---$ & HPC & .713 & .063 & 11.260 & $* * *$ & par_6 \\
\hline
\end{tabular}

Sumber : Data Primer (diolah), 2020

Artinya, setiap peningkatan harga cabai merah pada tingkat produsen/ petani sebesar 1 persen secara langsung akan mengakibatkan harga cabai merah pada tingkat konsumen di Kabupaten Aceh Jaya naik sebesar 0,713 persen. Hal ini sesuai dengan hasil penelitian yang dilakukan oleh Elvina, dkk (2016). 


\begin{tabular}{|c|c|c|c|}
\hline Tabel & $\begin{array}{c}5 \quad \text { Direct } \\
\text { Independen } \\
\text { Dependen }\end{array}$ & $\begin{array}{c}\text { Effect } \\
\text { Terhadap }\end{array}$ & $\begin{array}{l}\text { Variabel } \\
\text { Variabel }\end{array}$ \\
\hline & HPUK & PROD & HPC \\
\hline HPC & -.003 & -.376 & .000 \\
\hline HKC & -.043 & -.127 & .713 \\
\hline
\end{tabular}

Sumber : Data Primer (diolah), 2020

Untuk mengetahui keberadaan pengaruh tidak langsung variabel independen terhadap variabel independen, digunakan uji signifikansi dengan uji $Z$ Sobel. Berdasarkan tabel diatas, produksi cabai merah secara signifikan berpengaruh tidak langsung terhadap harga cabai merah pada tingkat konsumen. Hal ini ditunjukkan dengan $p$ value dari uji $Z$ Sobel sebesar 0,032 lebih kecil dari 0,10. Hasil uji ini menunjukkan bahwa produksi cabai merah secara signifikan berpengaruh terhadap harga cabai merah pada tingkat konsumen melalui harga cabai merah pada tingkat produsen/ petani di Kabupaten Aceh Jaya. Ini berarti produksi cabai merah memengaruhi harga cabai merah pada tingkat produsen/ petani terlebih dahulu selanjutnya harga cabai merah pada tingkat produsen/ petani baru memengaruhi harga cabai merah pada tingkat konsumen. Sebaliknya, harga pupuk urea tidak signifikan berpengaruh secara tidak langsung terhadap harga cabai merah pada tingkat konsumen. Hal ini ditunjukkan dengan $p$-value dari uji $Z$ Sobel sebesar 0,986 lebih besar dari 0,10.

Koefisien pengaruh tidak langsung variabel produksi cabai merah sebesar 0,268 . Artinya, setiap peningkatan produksi sebesar 1 persen akan mengakibatkan harga cabai merah pada tingkat konsumen turun sebesar 0,268 persen melalui penurunan harga cabai merah pada tingkat produsen/ petani. Ini berarti jika produksi cabai merah meningkat maka harga cabai merah pada tingkat produsen/ petani akan naik. Selanjutnya, kenaikan harga cabai merah pada tingkat produsen/ petani akan mengakibatkan harga cabai merah pada tingkat konsumen akan naik. Hal ini sesuai dengan hasil penelitian yang dilakukan oleh Elvina, dkk (2016).

Tabel 6 Hasil Uji Signifikansi Indirect Effect dengan $Z$ Sobel

\begin{tabular}{ccc}
\hline Pengaruh Tidak Langsung & Z Sobel & P-Value \\
\hline PROD -> HPC -> HKC & $-2,146$ & 0,032 \\
HPUK -> HPC -> HKC & $-0,017$ & 0,986 \\
\hline
\end{tabular}

Sumber : Data Primer (diolah), 2020

Harga Pupuk Urea tidak secara signifikan berpengaruh terhadap harga cabai merah baik pada tingkat produsen/ petani maupun pada tingkat konsumen.

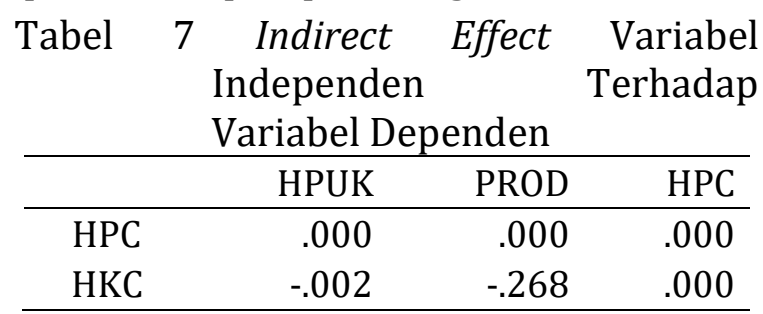

Sumber : Data Primer (diolah), 2020
Salah satu penyebabnya adalah preferensi petani di Kabupaten Aceh Jaya untuk menggunakan pupuk jenis lainnya misal pupuk NPK atau pupuk organik seperti pupuk kandang. Dengan demikian, kenaikan harga pupuk urea tidak serta merta mengakibatkan harga cabai merah di Kabupaten Aceh Jaya karena masih ada barang pengganti pupuk urea tersebut. 


\section{SIMPULAN}

Harga cabai merah di Kabupaten Aceh Jaya baik pada tingkat produsen/ petani maupun konsumen secara langsung dipengaruhi oleh produksi cabai merah. Pemerintah daerah melalui dinas terkait sebaiknya memberikan dukungan secara nyata dalam pengembangan produksi cabai merah di Kabupaten Aceh Jaya dengan memperhatikan kebutuhan petani cabai merah dalam melakukan produksi, seperti ketersediaan benih dan pupuk agar petani terpacu untuk menanam cabai merah. Dengan demikian, ini akan mendorong tumbuhnya sentrasentra produksi cabai merah di Kabupaten Aceh Jaya. Rekomendasi kebijakan lainnya yang dapat disampaikan adalah pemerintah perlu mengembangkan penanaman cabai merah diluar musim (off season) dan pengaturan penanaman cabai sehingga mampu mencukupi kebutuhan pada saat pasokan berkurang. Kemudian, ada indikasi transmisi harga cabai merah pada tingkat produsen/ petani ke konsumen di Kabupaten Aceh Jaya. Pemerintah daerah melalui dinas terkait disarankan menetapkan harga cabai merah tertinggi (ceiling price) dan harga terendah (floor price) agar pedagang tidak semaunya menaikkan atau menurunkan harga cabai merah sehingga ada kepastian harga untuk petani serta terbangun motivasi petani untuk menanam cabai merah. Selan itu, penetapan harga dilakukan untuk melindungi daya beli konsumen terhadap komoditas cabai merah di Kabupaten Aceh Jaya.

\section{DAFTAR PUSTAKA}

Darma, D.C., Pusriadi, Tommy, \& Hakim, Y. P. (2018). Dampak Kenaikan
Harga Komoditas Sembako Terhadap Tingkat Inflasi Di Indonesia. Samarinda: Sekolah Tinggi Ilmu Ekonomi Samarinda.

Elvina, Firdaus, Muhammad, \& Fariyanti, Anna. (2016). Transmisi Dan Pembentukan Harga Cabe Merah Serta Perilaku Pasar Antar Lembaga Pemasaran Cabe Merah Di Indonesia. Bogor: Institut Pertanian Bogor.

Fajri, Rahmatul, Fauzi, T, \&. Indra. (2017).

Analisis Faktor-Faktor Yang Memengaruhi Harga Cabai Merah Di Kota Banda Aceh. Jurnal Agribisnis Mahasiswa Pertanian Unsyiah, 2 (3).

Farid, M. dan N. A. Surbekti. (2012). Tinjauan Terhadap Produksi, Konsumsi, Distribusi Dan Dinamika Harga Cabai Di Indonesia. Bulletin Ilmiah Litbang Perdagangan, 6 (2).

Firdaus, Muhamad. (2012). Manajemen Agibisnis, Cetakan Keempat. Jakarta: Bumi Aksara.

MacKinnon, D. P., Warsi, G., \& Dwyer, J. H. (1995). A Simulation Study of Mediated Effect Measures. Multivariate Behavioral Research, 30.

Nauly, Dahlia. (2016). Fluktuasi Dan Disparitas Harga Cabai Di Indonesia. Jurnal Agrosains Dan Teknologi, 1 (1). Nurvitasari, Maya Eka, Suwandari, Anik, \& Suciati, Luh Putu. (2018). Dinamika Perkembangan Harga Komoditas Cabai Merah (Capsicum Annuum L) Di Kabupaten Jember. JSEP, 11 (1).

Saptana, Sunarsih, dan Kurnia Suci Indraningsih. (2006). Mewujudkan Keunggulan Komparatif Menjadi Keunggulan Kompetitif Melalui Pengembangan Kemitraan Usaha Hortikultura. Forum Penelitian Agro Ekonomi, 24 (1).

Sukirno, Sadono. (2005). Pengantar Teori Mikroekonomi Edisi Ketiga. Jakarta: PT. Indeks.

Wijayanti, Mutiara, Hadi, M Syamsoel, \& Pramono, Eko. (2013). Pengaruh 
Pemberian Tiga Jenis Pupuk Kandang Dan Dosis Urea Pada Pertumbuhan Dan Hasil Tanaman Cabai (Capssicum Annum L.). J. Agrotek Tropika, 1 (2).

Windhy, Adhis Millia, Suci, Yunisa Tri, \& Jamil, Ahmad Syariful. (2018).
Analisis Peramalan Harga Bawang Merah Nasional Dengan Pendekatan Model ARIMA. Prosiding Seminar Nasional Fakultas Pertanian Universitas Jambi Pembangunan Pertanian Berkelanjutan Berbasis Sumberdaya Lokal. 